\title{
PAHs Content of Tar Produced from Fischer Assay of Medium Rank C Bituminous South African Coal
}

\author{
T.C Khethane, E. Fosso-Kankeu*, F. Waanders, J. Bunt
}

\begin{abstract}
Coal is the major source of primary energy in South Africa and will likely remain the main energy source for the next 100 years. Thermal processing of coal results in the production of tar among other products. Tar is considered as one of the main of polycyclic aromatic hydrocarbons (PAHs) which are toxic and carcinogenic. To determine the PAHs content of tar produced from local coal, the Fischer Assay was simulated in this study and the tar produced was analysed using GC-MS to determine the PAHs content. It was found that the tar yield from the tested coal could be considerable under specific conditions while tar contained mostly lighter PAHs with a dominance of naphtalene.

This preliminary study allowed to predict the tar yield during thermal processing of local coal and their PAHs content, further investigations are needed to practically determine the tar yield.
\end{abstract}

Keywords - Bituminous coal, tar, PAHs, Fischer Assay.

\section{INTRODUCTION}

Currently, the world primary energy needs are mainly dependent on coal processing. This is more profound in developing countries like South Africa where $72 \%$ of the primary energy is derived from Coal [1]. In the process of energy generation value chain, being mining, beneficiation or energy production, major environmental issues are experienced. Although coal is a non-renewable energy source, its abundance and flexible nature make it an ideal source of energy. The conversion of raw coal into usable energy or chemicals is mainly achieved via combustion, liquefaction, fast and slow pyrolysis and gasification depending on end user requirements [2]. The present paper focuses on the simulation of coal pyrolysis followed by analysis of the content of the tar produced. During pyrolysis, energy is added in the form of heat and coal is converted to tar, char, hydrocarbons and gases. The overall operating conditions such as the atmosphere,

Manuscript received August 9, 2014. (Write the date on which you submitted your paper for review.) This work was supported in part by the U.S. Department of Commerce under Grant BS123456 (sponsor and financial support acknowledgment goes here).

F. A. Author is with the National Institute of Standards and Technology, Boulder, CO 80305 USA

S. B. Author was with Rice University, Houston, TX 77005 USA. He is now with the Department of Physics, Colorado State University, Fort Collins, CO 80523 USA.

T. C. Author is with the Electrical Engineering Department, University of Colorado, Boulder, CO 80309 USA, on leave from the National Research Institute for Metals, Tsukuba, Japan. temperature, pressure and rank of coal (lignite, anthracite or bituminous or sub-bituminous) are directly and indirectly linked to the process efficiency and product quality and distribution [3]. To ensure high tar yield during pyrolysis a continuous system and high heating rates are imperative to avoid secondary reactions [4].

There are many effective ways of studying coal pyrolysis, however the effective and reliable method is Fischer Assay due to the fact that it handles large quantities and different particle size distribution [5]. During the Fisher Assay pyrolysis method, devolatisation of the coal produces char and volatiles are evaporated. After the heating process, at room temperature, the volatiles together with condensable materials are separated from char. The condensable material and volatiles contain water, tar and gases. It is imperative to ensure the repeatability of the experiments as the Fisher Assay method requires knowledge and skill of the analyst during the operation of the setup. The mass of the produced tar and water will be determined by atmospheric distillation.

The effect of temperature, pressure and reaction atmosphere on coal pyrolysis product distribution and quality has been studied and well documented. Several studies have focused on the effect of different components in the pyrolysis atmosphere, such as $\mathrm{N}_{2}, \mathrm{H}_{2}, \mathrm{CO}_{2}$ or steam. Wang [6] investigated the effect of pressure on the tar yield from pyrolysed coal using a fixed bed reactor. The particle size distribution of the coal was less than 150 microns and the results showed the highest yield was obtained when using a combination of $\mathrm{CO}_{2}$ reforming methane and coal pyrolysis (CRMP) at $750^{\circ} \mathrm{C}$. The results also revealed that $\mathrm{N}_{2}$ produced a low yield of tar [6]. Fildago [4] also studied the effect of reaction atmosphere at $700^{\circ} \mathrm{C}$ and from the results concluded that $\mathrm{N}_{2}$ atmosphere yields less tar (1.9\%wt.) as opposed to a combination of steam $/ \mathrm{H}_{2} / \mathrm{CO}$ [4].

The tar produced from such processes generally contains high concentrations of polycyclic aromatic hydrocarbons (PAHs) which are reported to be toxic and carcinogenic. The discharge of such tar in the environment could result in the pollution of surface and ground waters; this will therefore contribute to more water stress as many sources are already polluted by mining activities [7 - 17].

In this study the tar yield from of medium rank $\mathrm{C}$ bituminous South African coal coal treated by Fischer Assay was predicted from the composition of coal and the PAHs in the tar was determined through GC-MS analysis. 


\section{METHOD}

\section{A. Coal Sample and Characterization}

South African coal sample from the Witbank coal seam was prepared to a size range of +212 to 1000 microns as specified by ISO 647. Table 1 shows the proximate analysis of the raw, parent coal.

\begin{tabular}{|c|c|} 
TABLE 1: FEED CHRACTERISATION \\
\begin{tabular}{|c|c|}
\hline Item & Value \\
\hline Volatiles (dry) & 23.2 \\
\hline Gross calorific value (MJ/Kg) & 19.33 \\
\hline Ash & 35.1 \\
\hline Inherent moisture & 1.7 \\
\hline
\end{tabular}
\end{tabular}

According to proximate analysis, this was a high ash (35.1\%) coal sample containing $23.2 \%$ volatiles and $40 \%$ fixed carbon on a dry basis.

\section{B. Tar Experiment Setup}

The Fischer Assay experiment was performed according to ISO 647 using a modified automated Fisher assay setup. The setup is presented in Figure 1. The temperature of the oven and coal bed was monitored periodically.

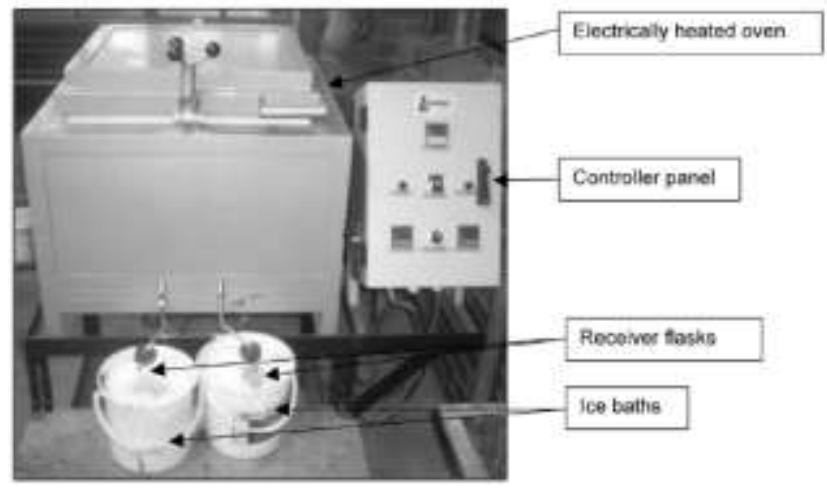

Fig. 1: The automated Fischer Assay setup adapted from Roets [18]

The reactor inside the oven is manufactured from stainless steel to allow high temperature $\left(1000^{\circ} \mathrm{C}\right)$ pyrolysis to be conducted. The coal sample is placed inside the reactor and heated to the required temperature under the $\mathrm{N}_{2}$ atmosphere which is blown continuously. The blowing of nitrogen also helps in purging the reactor and to minimize the secondary reaction of tars. The condensable materials were condensed in a flask immersed in an ice bath and the non-condensable volatiles were allowed to escape to the atmosphere. The condensed material mainly tar was measure and send for analysis in a GC-MS.

\section{Gas Chromatography-Mass Spectrometry (GC-MS)}

All tar samples were analyzed using a GC-coupled with MS for quantification and identification of PAHs. Samples for GC-MS analysis were prepared by dissolving tar into dichloromethane in vials. Approximately 1 microliter of prepared sample was injected into the GC column.

\section{RESULTS AND DISCUSSION}

\section{A. Mineralogical Composition of Coal}

The XRD analysis revealed the mineralogical composition of the coal feed; kaolinite, quartz and dolomite were the most abundant minerals in the coal; these minerals have been reported as the most common minerals in coal [19 - 23]; however, the coal feed also contain a considerable proportion of highly disordered materials in the form of amorphous carbon [24].

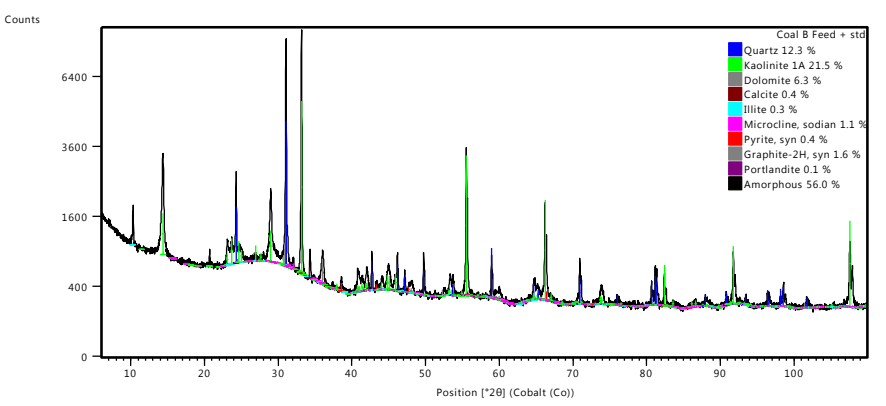

Fig. 2. XRD spectra of coal.

\section{B. Prediction of Tar Yield}

Tars are produced from coal in several industries to the advance of chemical applications. According to work done by previous researchers $[25,26]$, the type of coal is likely to affect the yield of tar generated and therefore the composition of the recovered by-products which include PAHs. The chemical characterization of the coal used in this study allowed to determine the rate of parameters listed in Table 2. These parameters could be used to predict the tar yield according to the estimative equation (1) which was developed by Okumura [26] by applying the least squares approximation to the yield data for various coals.

$\mathrm{Y}_{\mathrm{tar}}=30.4 \times(\mathrm{H} / \mathrm{C})-14[\mathrm{wt} \%]$

Where $Y_{\text {tar }}$ is the tar yield and $\mathrm{H} / \mathrm{C}$ is the atomic ratio of $\mathrm{H} / \mathrm{C}$

Using equation (1), the tar yield was calculated and the value obtained (9.6 w\% or $0.096 \mathrm{~g} / \mathrm{g}$ coal) indicates that tar yield in this was in the average range compared to the yield obtained by Okumura [26] from 19 coal samples. According to the same study, the PAH yield in the tar will increase with increase tar yield; implying that a non-negligible amount of PAHs was expected to be produced from the coal studied.

\begin{tabular}{lc} 
TABLE 2 & CHEMICAL COMPOSITION OF COAL \\
\hline Parameters & Value $\%$ \\
\hline Carbon content & 49 \\
Hydrogen content & 3.17 \\
Nitrogen content & 1.02 \\
Oxygen content & 8.49 \\
\hline
\end{tabular}

\section{PAHs in Coal Tar}

The polyaromatic hydrocarbons (PAHs) have been reported as the major components of coal-derived products and thermally cracked petroleum oils [27]; the PAH are toxic and/or mutagenic in biological systems and must therefore be seriously considered in coal tar. The coal tar PAH composition was 
determined using GC-MS and the results are shown in Table 3. A variety of PAH were observed in the coal tar with a dominance of naphtalene. The toxicities of PAH have been reported to be related to specific structures and positions of ring subtitution [27]. The PAHs identified in this studied are mostly categorized as lighter PAHs, because of their lower molecular weight; It has been reported that PAHs of lower molecular weight are less toxic compared to the heavier PAHs [28]; however, their toxicity may become more significant when they react with other pollutants [29].

TABLE 3: COAL TAR PAH COMPOSITION

\begin{tabular}{lcc}
\hline \multicolumn{1}{c}{ Compounds } & Area & Number of rings \\
\hline Naphtalene & 15.22 & 2 \\
1,4-Methanonaphthalene & 1.78 & 2 \\
1-Naphthalenecarbonitrile & 0.6 & 2 \\
Dibenzofuran & 0.6 & 3 \\
Anthracene & 0.77 & 3 \\
Phenanthrene & 1.01 & 3 \\
\hline
\end{tabular}

\section{CONCLUSION}

Tar was effectively produced from coal using the Fischer Assay. Based on the properties of coal, it was predicted that a considerable amount of tar could be produced from such coal. The PAHs identified in the tar by GC-MS are classified as lighter PAHs with the potential to become significantly toxic if reacted with other pollutants. If the tars generated through such processes are discharged in the environment without proper management, compounds such as the PAHs identified could be released in surface water with detrimental impact on the aquatic system. This may exacerbate the problem of water pollution already reported in our previous works [30 - 34].

\section{ACKNOWLEDGMENTS}

The authors are grateful to the sponsor from the North-West University and the National Research Foundation in South Africa. Any opinion, findings and conclusions or recommendations expressed in this material are those of the authors and therefore the NRF does not accept any liability in regard thereto.

\section{REFERENCES}

[1] BP Statistical Review of world energy. 2013. Available from: Http://www.bp.com/content/dam/bp/pdf/statistical

review/statistical_review_of_world_energy_2013.pdf. Date Accessed: 26 August 2014.

[2] Miller, Bruce G. 2005. Coal Energy System.

[3] Casal, M., M... Diez, R. Alverez, and C. Barriocanal. 2008. "Primary Tar of Different Coking Coal Ranks, Int. J. Coal Geol. 76 (2008) 237 - 242." Coal Geology 76:237-42.

https://doi.org/10.1016/j.coal.2008.07.018

[4] Fidalgo, Beatriz, Daniel Van Niekerk, and Marcos Millan. 2014. "The Effect of Syngas on Tar Quality and Quantity in Pyrolysis of a Typical South African Inertinite-Rich Coal." FUEL 134:90-96. https://doi.org/10.1016/j.fuel.2014.05.032

[5] Slaghuis, Johan H., and Natasja Raijmakers. 2004. "The Use of Thermogravimetry in Establishing the Fischer Tar of a Series of South African Coal Types." Fuel 83:533-36. https://doi.org/10.1016/j.fuel.2003.10.002
[6] Wang, Pengfei, Lijun Jin, Jiahe Liu, Shengwei Zhu, and Haoquan Hu. 2013. "Analysis of Coal Tar Derived from Pyrolysis at Different Atmospheres." Fuel 104:14-21. https://doi.org/10.1016/j.fuel.2010.06.041

[7] Fosso-Kankeu E, Mulaba-Bafubiandi A, Mamba BB, Barnard TG. 2009. Mitigation of $\mathrm{Ca}, \mathrm{Fe}$, and $\mathrm{Mg}$ loads in surface waters around mining areas using indigenous microorganism strains. Journal of Physics and Chemistry of the Earth, Vol 34, pp 825-829. https://doi.org/10.1016/j.pce.2009.07.005

[8] Fosso-Kankeu E, Mulaba-Bafubiandi A, Mamba BB, Marjanovic L, Barnard TG. 2010. A comprehensive study of physical and physiological parameters that affect biosorption of metal pollutants from aqueous solutions. Journal of Physics and Chemistry of the Earth, Vol 35, pp 672-678. https://doi.org/10.1016/j.pce.2010.07.008

[9] Fosso-Kankeu E, Mulaba-Bafubiandi A, Mamba BB, Barnard TG. 2011. Assessing the effectiveness of a biological recovery of nickel from tailings dumps. Journal of Minerals Engineering.Vol 24, pp 470-472. https://doi.org/10.1016/j.mineng.2010.11.007

[10] E. Fosso-Kankeu, AF Mulaba-Bafubiandi, BB Mamba and TG Barnard. 2011. Prediction of metal-adsorption behaviour in the remediation of water contamination using indigenous microorganisms. Journal of Environmental Management, 92 (10), pp 2786-2793. https://doi.org/10.1016/j.jenvman.2011.06.025

[11] Munyai AH, Fosso-Kankeu E, Waanders F. 2016. Mobility of metals from mine tailings using different types of organic acids: Batch leaching experiment. International Journal of Science and Research. 5: 520-527.

[12] Alusani Manyatshe, Elvis Fosso-Kankeu, Divan van der Berg, Nico Lemmer, Frans Waanders, Hlanganani Tutu. 2017. Metal retention potential of sediment and water quality in the Mooi River, South Africa. Desalination and Water Treatment. doi: 10.5004/dwt2017.20222.

[13] Elvis Fosso-Kankeu, Alusani Manyatshe, Frans Waanders. 2017. Mobility potential of metals in acid mine drainage occurring in the Highveld area of Mpumalanga Province in South Africa: Implication of sediments and efflorescent crusts. International Biodeterioration and Biodegradation. 119: 661-670. https://doi.org/10.1016/j.ibiod.2016.09.018

[14] Elvis Fosso-Kankeu, Hemant Mittal, Frans Waanders, Suprakas Sinha Ray. 2017. Thermodynamic properties and adsorption behaviour of hydrogel nanocomposites for cadmium removal from mine effluents. Journal of Industrial and Engineering Chemistry. 48: 151-161. https://doi.org/10.1016/j.jiec.2016.12.033

[15] A. Manyatshe, E. Fosso-Kankeu, D. van der Berg, N. Lemmer, F. Waanders, H. Tutu. 2017. Dispersion of inorganic contaminants in surface water in the vicinity of Potchefstroom. Physics and Chemistry of the Earth. 100: 86-93. https://doi.org/10.1016/j.pce.2017.04.008

[16] Fosso-Kankeu, Elvis; Mulaba-Bafubiandi, Antoine Floribert; Barnard, Tobias; Campana, Patricia (2013): Indirect implication of bacterial proteins in the biouptake of metals from aqueous solution. - In: Brown, A.; Figueroa, L. \& Wolkersdorfer, Ch.: Reliable Mine Water Technology (Vol II). - p. 843 - 849; ISBN: 978-0-615-79385-6-Volume 2, Denver, Colorado, USA (Publication Printers).

[17] E. Fosso-Kankeu, F. Waanders. 2014. Metal Ions Adsorption Affinity of Clay Materials from the North West Province of South Africa. An Interdisciplinary Response to Mine Water Challenges. International Mine Water Conference, August 2014 Xuzhou China. Editors, Sui, Sun \& Wang (Eds). 2014 China University of Mining andTechnology Press, Xuzhou, ISBN: 978-7-5646-2437-8. Pp374-378.

[18] Roets, Leon, John R. Bunt, Hein W. J. P. Neomagus, and Daniel Van Niekerk. 2014. "An Evaluation of a New Automated Duplicate-Sample Fischer Assay Setup according to ISO / ASTM Standards and Analysis of the Tar Fraction." Journal of Analytical and Applied Pyrolysis 106:190-96 https://doi.org/10.1016/j.jaap.2014.01.016

[19] Mackowsky, M.Th., 1968. Mineral matter in coal. In: Murchison, D.G., Westoll, T.S. (Eds.), Coal and Coal-Bearing Strata. Oliver and Boyd, London, pp. 309- 321.

[20] Ward, C.R., 1978. Mineral matter in Australian bituminous coals. Proceedings, Australasian Institute of Mining and Metallurgy. 267, 7- 25.

[21] Ward CR. 2002. Analysis and significance of mineral matter in coal seams. International Journal of Coal Geology. 50: $135-168$. 
https://doi.org/10.1016/S0166-5162(02)00117-9

[22] Harvey, R.D., Ruch, R.R., 1986. Mineral matter in Illinois and other US coals. In: Vorres, K.S. (Ed.), Mineral Matter in Coal Ash and Coal. American Chemical Society Symposium Series 301, pp. 10- 40.

[23] Palmer, C.A., Lyons, P.C., 1996. Selected elements and major minerals from bituminous coal as determined by INAA: implications for removing environmentally sensitive elements from coal. International Journal of Coal Geology 32, 151-166. https://doi.org/10.1016/S0166-5162(96)00035-3

[24] Sonibare OO, Haeger T and Foley SF. 2010. Structural characterization of Nigerian coals by X-ray diffraction, Raman and FTIR spectroscopy. Energy: 35: $5347-5353$. https://doi.org/10.1016/j.energy.2010.07.025

[25] K. Tanizawa, in: Proceedings of the 52nd Confer- ence on Coal Science, The Japan Institute of Energy, 2015, pp. ii-vii. http://ietd.iipnetwork.org/content/ scope- 21- next- generation- cokemaking- technology.

[26] Okumura Y. 2017. Effect of heating rate and coal type on the yield of functional tar components. Proceedings of the Combustion Institute. 36: $2075-2082$. https://doi.org/10.1016/j.proci.2016.09.020

[27] Nishioka M, Chang H-C and Lee ML. 1986. Structural characteristics of polycyclic aromatic hydrocarbon isomers in coal tars and combustion products. Environ. Sci. Technol. 20: 1023 - 1027. https://doi.org/10.1021/es00152a010

[28] Kim K-H, Jahan SA, Kabir E, Brown RJC. 2013. A review of airborne polycyclic aromatic hydrocarbons (PAHs) and their human health effects. Environment International. 60: 71-80. https://doi.org/10.1016/j.envint.2013.07.019

[29] Park JS, Wade TL, Sweet S. 2001. Atmospheric distribution of polycyclic aromatic hydrocarbons and deposition to Galveston Bay, Texas, USA. Atmos. Environ. 35: 3241 - 3249 https://doi.org/10.1016/S1352-2310(00)00503-3.

[30] F. Waanders, M. Nel, E. Fosso-Kankeu. 2014. Adsorption potential of bentonite clay and attapulgite applied for the desalination of sea water. $6^{\text {th }}$ International Conference on Green Technology, Renewable Energy and Environmental Engineering (ICGTREEE'2014). 27-28 November 2014, Cape Town-South Africa. Editors: Muzenda E. and Sandhu S. ISBN: 978-93-84468-08-8. Pp 275-279.

[31] Fosso-Kankeu E, Waanders F, Reitz M. 2014. Selective adsorption of heavy and light metals by natural zeolites. $6^{\text {th }}$ International Conference on Green Technology, Renewable Energy and Environmental Engineering (ICGTREEE'2014). 27-28 November 2014, Cape Town-South Africa. (Award Winning Paper). Editors: Muzenda E. and Sandhu S. ISBN: 978-93-84468-08-8. Pp 271-274.

[32] Elvis Fosso-Kankeu, Frans Waanders, Corinne Fraser. 2014. Bentonite clay adsorption affinity for anionic and cationic dyes. $6^{\text {th }}$ International Conference on Green Technology, Renewable Energy and Environmental Engineering (ICGTREEE'2014). 27-28 November 2014, Cape Town-South Africa. Editors: Muzenda E. and Sandhu S. ISBN: 978-93-84468-08-8. Pp 257-260. Pp 257-260.

[33] Fosso-Kankeu Elvis, Van der Berg Charl M., Frans B. Waanders. 2014. Physico-chemical activation of South African bentonite clay and impact on metal adsorption capacity. $6^{\text {th }}$ International Conference on Green Technology, Renewable Energy and Environmental Engineering (ICGTREEE'2014). 27-28 November 2014, Cape Town-South Africa. Editors: Muzenda E. and Sandhu S. ISBN: 978-93-84468-08-8. Pp 247-252.

[34] Elvis Fosso-Kankeu, Frans Waanders, Antoine F. Mulaba-Bafubiandi and Sibusiso Sidu. 2015. Leachability of suspended particles in mine water and risk of water contamination. $10^{\text {th }}$ ICARD/IMWA 2015; $10^{\text {th }}$ International Conference on Acid Rock Drainage \& IMWA Annual Conference. 21-24 April 2015 Santiago-Chile. Editors: Adrian Brown, Charles Bucknam, Joanna Burgess, Manuel Carballo, Devin Castendyk, Linda Figueroa, Lisa Kirk, Virginia McLemore, James McPhee, Mike O'Kane, Robert Seal, Jacques Wiertz, David Williams, Ward Wilson, Christian Wolkersdorfer. ISBN: 978-956-9393-28-0. Chap 4. Pp 1-9.

The corresponding author is currently an Associate Professor in the School of Chemical and Minerals Engineering at the North-West University (Potchefstroom-South Africa). He is an NRF rated researcher who has published journal articles, book chapters and book.

Prof Elvis Fosso-Kankeu has been the recipient of several merit awards 